\title{
DENDROCHRONOLOGICAL DATING OF AN ANTEBELLUM PERIOD HOUSE, FORSYTH COUNTY, GEORGIA, U.S.A.
}

\author{
GEORGINA DEWEESE WIGHT and HENRI D. GRISSINO-MAYER* \\ Laboratory of Tree-Ring Science \\ Department of Geography \\ The University of Tennessee \\ Knoxville, TN 37996 USA
}

\begin{abstract}
We examined tree rings from cross-sections of shortleaf pine (Pinus echinata Mill.) timbers extracted from a house in Forsyth County, Georgia, that was reportedly built in the mid-19th Century during the Antebellum Period (pre-1860). Our goals were to (1) determine the probable construction year for the house to help assess its possible historical significance, and (2) create a new long-term reference chronology for the northern Georgia area where such chronologies are lacking. Sections of shortleaf pine were removed from the structure during a renovation project in 2001. Sixteen sections were used to build a floating treering chronology 217 years in length from series that crossdated conclusively with other series both graphically via skeleton plots and statistically via COFECHA. We then statistically evaluated the probable absolute temporal placement of this chronology using several regional tree-ring chronologies from the southeastern U.S. A statistically significant $(\mathrm{p}<0.0001)$ correlation between our chronology and a shortleaf pine chronology from Clemson, South Carolina, anchors our chronology between 1652-1868. Two missing rings are probable in the early portion of our chronology, but we currently do not have a sufficient number of samples to conclusively identify their exact placement. No cluster of outermost rings was found to support the reported construction date of 1851, although the outermost rings on 13 of 16 samples dated before 1851. This new chronology could aid further dating of wood from archaeological sites and historical structures, and establish an initial data set that could eventually provide important new insights about the climate of northern Georgia during the 17th-19th Centuries.
\end{abstract}

Keywords: dendrochronology, tree rings, Georgia, shortleaf pine, Pinus echinata Mill.

\section{INTRODUCTION}

The year of construction for a historic structure can be obtained by comparing the tree-ring patterns from wood samples taken from the structure with tree-ring patterns from either a local or regional reference chronology (Bannister 1969; Stahle and Wolfman 1985; Dean 1986). Crossdating ensures that all tree rings in samples from historic structures are assigned their correct calendrical year, thus enabling an assessment of the possible year of construction as well as the sequence of modifications made in later years (Dean 1996). Well-established with a long history of applications in the southwestern United States, dendroarchaeology has been only sparingly used in the

*Corresponding author: grissino@utk.edu. southeastern United States and only since the late 1970s (Stahle 1979; Langley 2000; Mann 2002; Bortolot et al. 2001). Earlier attempts at dating archaeological sites and structures in the southeastern U.S. were only partially successful (Hawley 1938; Bell 1952) and met with considerable skepticism (Nash 1999). In combination, these studies demonstrate the potential for using dendroarchaeological techniques for dating historic structures and Native American sites in the American Southeast.

A valuable contribution of tree rings collected from historical/archaeological contexts is the insight they provide on past climate. Many studies have reconstructed past climate on century (and longer) time scales from archaeological tree-ring data (Euler et al. 1979; D'Arrigo and Jacoby 1991; Dean and Funkhouser 1995) but, again, very few 
such studies have been conducted in the southeastern U.S. (see, however, Druckenbrod et al. 2003). Two reasons primarily account for this lack of research. First, the Southeast has a long history of widespread land clearing and timber exploitation since the 17 th Century that has removed older tree specimens required for developing reference tree-ring chronologies that can be used for dating archaeological/historical sites. Second, the decay rate of wood in the American Southeast is the highest of any location in the U.S. because warm, humid environments promote rapid fungal decay (Scheffer 1972). Well-preserved wood specimens are uncommon finds in archaeological sites in the southeastern U.S., but do occur (Hally 1988). To overcome these issues, climate information can be obtained from old-growth trees that have been incorporated into historical structures. If enough tree-ring chronologies in the southeastern U.S. can be extended to the 15th and 16th Centuries from wood from historical structures, it may be possible to (1) date wood and charcoal collections gathered from prehistoric (and post-European contact) Native American sites (Stahle 1979), and (2) extend information on past climate back in time.

During a renovation of an Antebellum Period house in Forsyth County, Georgia (a suburb of Atlanta), we were offered a rare opportunity to analyze cross-sections of shortleaf pine trees (Pinus echinata Mill.) that were extracted from selected areas of the house. If the house was indeed built during the Antebellum Period (pre-1860) as claimed by its owner, the trees used in its construction could potentially have been harvested from old-growth stands. Such trees would be older and have grown more slowly than contemporary trees. Currently, no well-replicated, long ( $>200$ years) tree-ring chronology exists for northern Georgia (International Tree-Ring Data Bank [ITRDB] 2003). Our study had two primary objectives: (1) determine which year or the general period in which this house was likely constructed and (2) develop a multicentury tree-ring chronology for northern Georgia. This study represents the first dendrochronological dating of a historic structure in the state of Georgia, and the data could be used for subsequent archaeological, historical, and climatic studies in the region.

\section{HOUSE AND SITE DESCRIPTION}

The house is located at 100 Kelly Mill Road in Cumming, Georgia, approximately $80 \mathrm{~km}$ northnortheast of Atlanta (Figure 1). This region of northern Georgia was occupied by Cherokee Indians until 1838 (Wilms 1991). In 1831, the state of Georgia ordered that the Cherokee lands be surveyed in preparation for a state land lottery that would take place the following year (Wilms 1973). Forsyth County was established in 1831 from these lands with the city of Cumming as its county seat (Shadburn 1990). In 1837, Robert Montgomery bought the land on which the house sits plus 40 acres (16 hectares) of forest land through this sale. On the forested portion of the land, he established a sawmill; it was from this forest that the shortleaf pines used to build the house were likely cut. Montgomery died in 1852, leaving the house to his wife (Bryan Redd, personal communication, 29 July 2002).

The house is described as an American folk gable front and wing design (Figure 2). This design was popular during the Greek Revival period in American architecture between ca. 1820-1860 (Carley 1994). In the American South, this design is traditionally called "Antebellum Architecture" (Gleason 1987) and was the dominant architectural style between ca. 1830-1862 ("antebellum" means "before the [Civil] war"). The house is located in a residential area approximately 0.3 miles $(0.5 \mathrm{~km})$ from the Forsyth County Court House in Cumming. Although in a residential area, no other houses were built adjacent to it, and the oldest nearby house in the vicinity was built $c a .1900$. The owner believes that the surrounding countryside was cleared in the late 1800s and early 1900s for agricultural purposes. The shortleaf pine forest that remained was reportedly cut down by the U.S. Army during World War II (Bryan Redd, personal communication, 16 February 2002).

\section{METHODS}

In 2002, 18 sections of wood were removed from the house during a renovation project. These sections were surfaced using progressively finer sandpaper, beginning with ANSI 100-grit (125$149 \mu \mathrm{m})$ and ending with ANSI 320-grit (32.5-36 


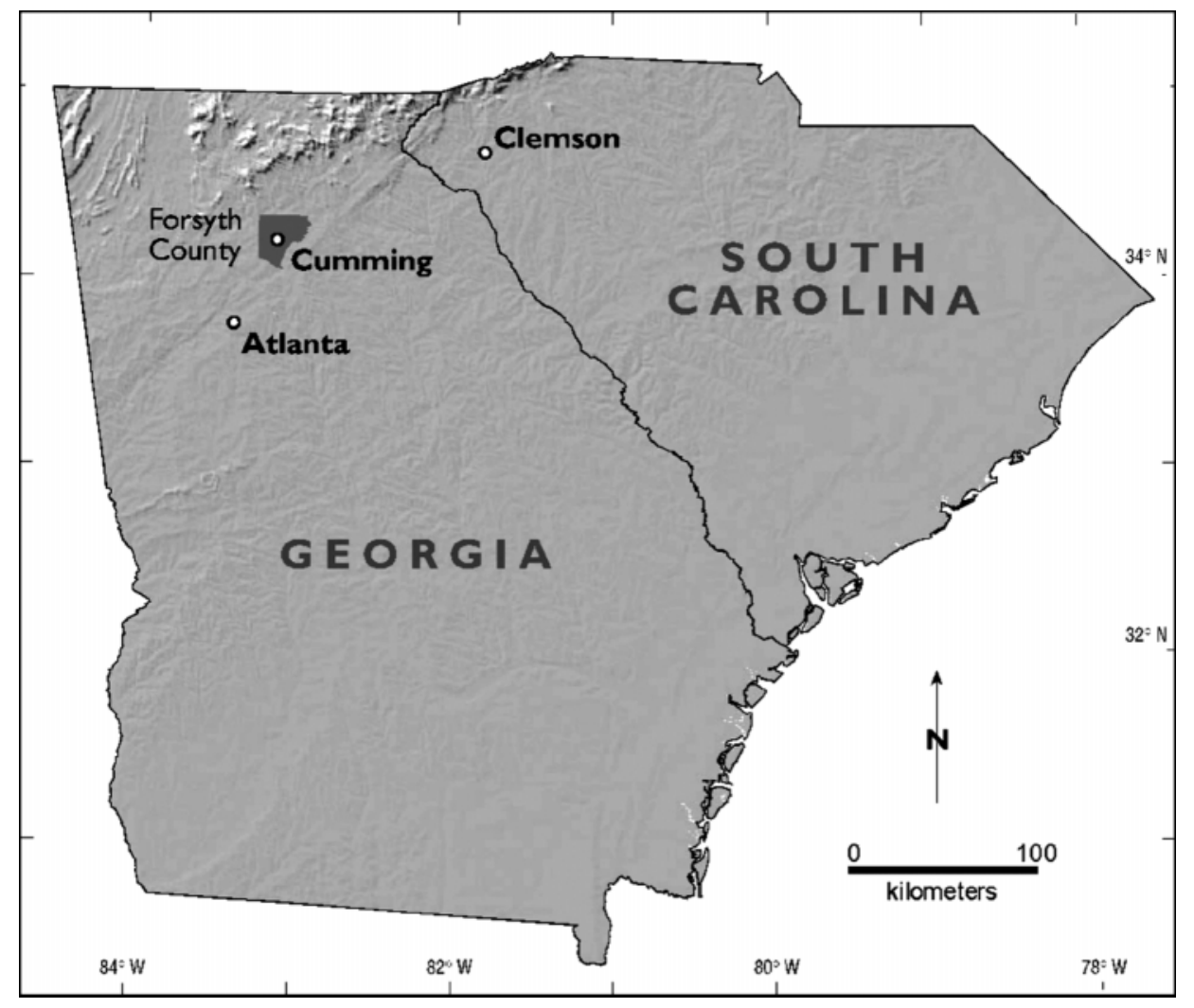

Figure 1. Locations of the (1) Antebellum Period house in Forsyth County, Georgia, from which we developed our shortleaf pine chronology, and (2) Clemson Forest, South Carolina, from where the ITRDB reference chronology SC003 was developed.

$\mu \mathrm{m})$ (Orvis and Grissino-Mayer 2002). We began the dating process by creating skeleton plots of all series to date each series relatively against all others. The innermost incomplete ring on each sample was set to the relative year " 0 " and every subsequent tenth ring was marked by mechanical pencil.

To help assign absolute dates to all samples, we measured all tree-ring widths to the nearest 0.01 $\mathrm{mm}$ using a Velmex measuring system interfaced with Measure $\mathrm{J} 2 \mathrm{X}^{\circledR}$ measuring software. The measurement series from the 18 undated samples were next statistically crossdated to all other undated series using COFECHA (Holmes 1983; GrissinoMayer 2001) to corroborate the plotted relative positions in time. When a series was shown to be significantly correlated $(\mathrm{p}<0.001)$ with other series, we used the EDRM (Edit Ring Measurement) program (Holmes 1992a) to shift the rings in the series so that the relative years of each series would be consistent. Once all series were dated relative to each other, we confirmed our relative placements again using COFECHA, testing 40year segments (with a 20-year overlap) of each series with the respective segment created from all other series (Grissino-Mayer 2001). We used the CRONOL program (Cook 1985; Holmes 1992b) to create a final chronology from all relatively dated series. We used the STANDARD chronology to statistically crossdate our Forsyth County chronology to regional chronologies from the southeastern U.S. (Table 1) (ITRDB 2003), again using COFECHA, in an attempt to anchor our floating chronology. These regional chronologies were selected to represent similar lower-elevation sites in the Piedmont physiographic province. The suggested temporal placements made by COFECHA were visually assessed using line and skeleton plots. All suggested placements made by COFECHA had to be convincing both graphically and statistically (Grissino-Mayer 2001). 


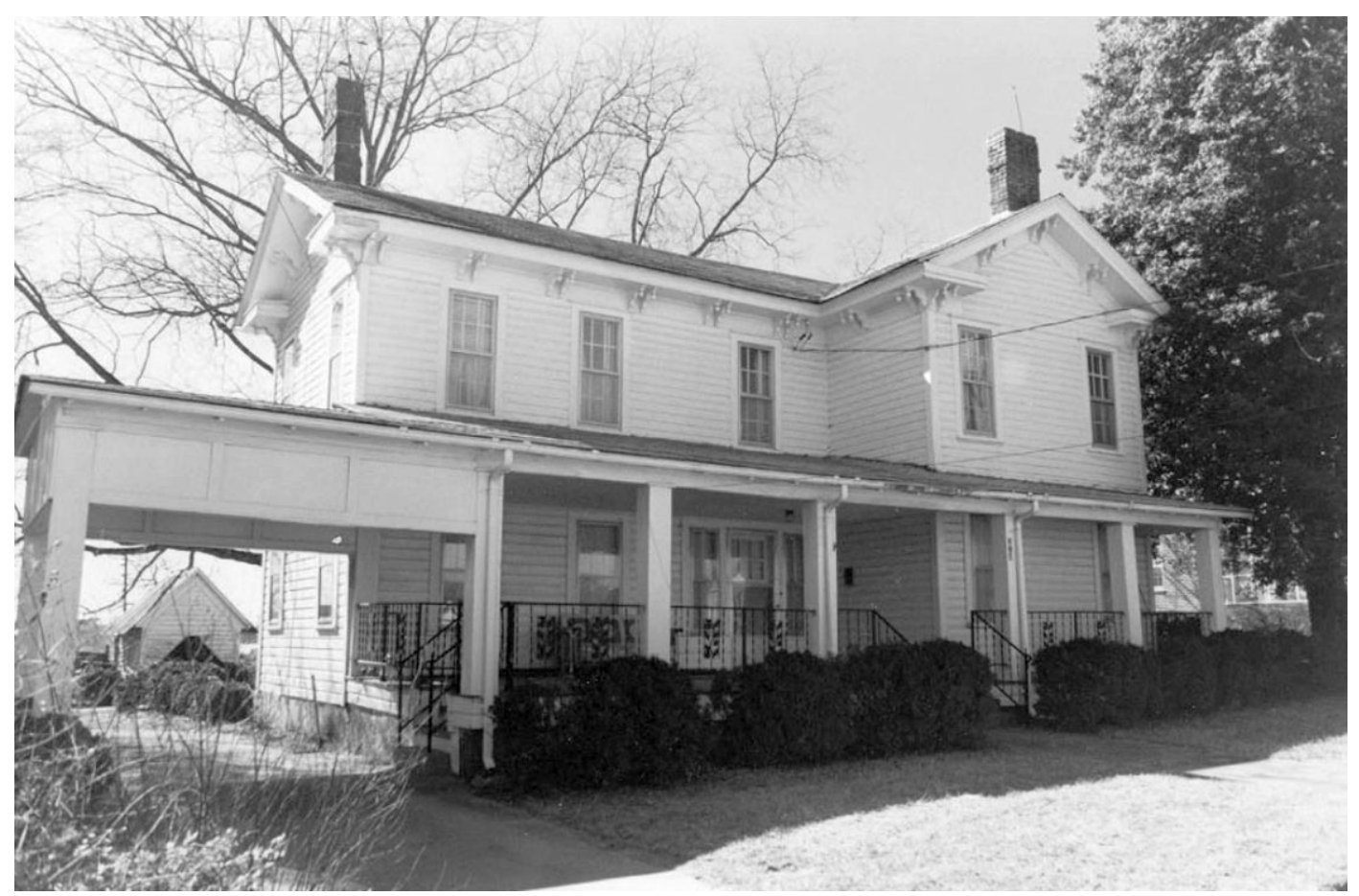

Figure 2. The house located at 100 Kelly Mill Road in Cumming, Georgia, described as an American folk gable front and wing design.

\section{RESULTS}

Of our original 18 measured series, two could not be confidently placed relative to the other series nor to the regional master chronologies and were not included in further analyses. We observed a high degree of correspondence among all

Table 1. Regional reference chronologies used to crossdate the floating Forsyth County shortleaf pine chronology.

\begin{tabular}{|c|c|c|c|}
\hline Chronology $^{1}$ & Location & Species & Range \\
\hline GA001 & $33^{\circ} 57^{\prime} \mathrm{N}, 83^{\circ} 19^{\prime} \mathrm{W}$ & shortleaf pine & 1821-1986 \\
\hline AL001 & $34^{\circ} 20^{\prime} \mathrm{N}, 87^{\circ} 27^{\prime} \mathrm{W}$ & white oak & 1679-1985 \\
\hline NC004 & $35^{\circ} 13^{\prime} \mathrm{N}, 83^{\circ} 58^{\prime} \mathrm{W}$ & white oak & $1641-1983$ \\
\hline SC003 & $34^{\circ} 42^{\prime} \mathrm{N}, 82^{\circ} 52^{\prime} \mathrm{W}$ & shortleaf pine & 1684-1973 \\
\hline TN005 & $35^{\circ} 42^{\prime} \mathrm{N}, 84^{\circ} 53^{\prime} \mathrm{W}$ & white oak & 1651-1982 \\
\hline TN008 & $36^{\circ} 13^{\prime} \mathrm{N}, 84^{\circ} 05^{\prime} \mathrm{W}$ & white oak & 1633-1980 \\
\hline TN009 & $35^{\circ} 27^{\prime} \mathrm{N}, 85^{\circ} 34^{\prime} \mathrm{W}$ & eastern hemlock & 1613-1985 \\
\hline TN021 & $35^{\circ} 37^{\prime} \mathrm{N}, 85^{\circ} 26^{\prime} \mathrm{W}$ & chestnut oak & 1750-1997 \\
\hline TN022 & $35^{\circ} 37^{\prime} \mathrm{N}, 83^{\circ} 56^{\prime} \mathrm{W}$ & shortleaf pine & 1683-1997 \\
\hline
\end{tabular}

${ }^{1}$ Chronologies obtained from the International Tree-Ring Data Bank (ITRDB 2003): $\mathrm{GA}=$ Georgia, $\mathrm{AL}=$ Alabama, $\mathrm{NC}=$ North Carolina, $\mathrm{SC}=$ South Carolina, and $\mathrm{TN}=$ Tennessee. 40-year segments for the remaining series as indicated by the statistically significant correlation coefficients in nearly all comparisons (Table 2). The interseries correlation coefficient (which indicates the quality of the crossdating among all series) for our shortleaf pine samples $(\mathrm{n}=16)$ from the Antebellum Period house was 0.57 (Table 3 ). The mean sensitivity, a measure of the relative differences in width between adjacent rings (Fritts 2001), was 0.24. This value is higher than the mean sensitivity for loblolly pines (Pinus taeda L.) growing in northern Georgia (Grissino-Mayer et al. 1989) and higher than the average mean sensitivity for shortleaf pines growing elsewhere in the southeastern U.S. (Dewitt and Ames 1978). COFECHA flagged only two 40-year segments for possible errors out of the 81 segments tested (Table 3). Closer inspection of these two segments indicated significant correlations $(\mathrm{p}<0.01)$ at the current dated position, while the alternative placements suggested by COFECHA were unrealistic.

When we compared the floating shortleaf pine chronology with each individual Southeastern re- 
Table 2. Correlation coefficient matrix from COFECHA comparing 40-year segments of each series (lagged 20 years) with a chronology made from the remaining series (Grissino-Mayer 2001). All coefficients are statistically significant $(\mathrm{p}<0.01$, most at $\mathrm{p}<0.001$ ). No correlations were possible for the earliest segment because only one sample (ATL002) spanned the period 1652-1683. Series ATL001 and ATL014 were later determined to be from the same tree.

\begin{tabular}{|c|c|c|c|c|c|c|c|c|c|}
\hline \multirow[b]{2}{*}{ Series } & \multicolumn{9}{|c|}{ 40-year Ring Segment } \\
\hline & $20-59$ & $40-79$ & $60-99$ & $80-119$ & $100-139$ & $120-159$ & $140-179$ & $160-199$ & $180-219$ \\
\hline ATL002 & 0.77 & 0.77 & 0.60 & 0.62 & 0.67 & 0.67 & & & \\
\hline ATL010 & 0.58 & 0.58 & 0.71 & 0.71 & & & & & \\
\hline ATL008 & 0.51 & 0.46 & 0.40 & 0.70 & 0.83 & 0.83 & & & \\
\hline ATL016 & & 0.80 & 0.72 & 0.70 & 0.69 & & & & \\
\hline ATL003 & & 0.43 & 0.65 & 0.58 & 0.46 & 0.56 & 0.49 & & \\
\hline ATL014 & & 0.47 & 0.52 & 0.59 & 0.46 & 0.44 & & & \\
\hline ATL012 & & 0.55 & 0.56 & 0.78 & 0.68 & 0.69 & & & \\
\hline ATL005 & & & 0.48 & 0.55 & 0.40 & & & & \\
\hline ATL015 & & & 0.61 & 0.71 & 0.74 & & & & \\
\hline ATL013 & & & 0.73 & 0.68 & 0.52 & 0.57 & 0.42 & 0.32 & \\
\hline ATL001 & & & 0.61 & 0.68 & 0.64 & 0.62 & 0.59 & 0.57 & 0.59 \\
\hline ATL017 & & & 0.58 & 0.64 & 0.59 & 0.61 & 0.62 & 0.56 & 0.59 \\
\hline ATL007 & & & 0.48 & 0.55 & 0.72 & 0.66 & & & \\
\hline ATL018 & & & 0.50 & 0.50 & 0.56 & 0.53 & 0.54 & 0.42 & 0.37 \\
\hline ATL011 & & & & 0.43 & 0.60 & 0.64 & & & \\
\hline ATL009 & & & & & 0.37 & 0.42 & 0.59 & 0.51 & \\
\hline Average & 0.62 & 0.58 & 0.58 & 0.63 & 0.60 & 0.60 & 0.54 & 0.48 & 0.52 \\
\hline
\end{tabular}

gional chronology, only one match was found that was convincing both statistically and graphically. Our floating chronology showed a significant correlation $(\mathrm{r}=0.43, \mathrm{p}<0.0001)$ with the $\mathrm{SC003}$ shortleaf pine chronology from Clemson Forest, South Carolina (Cleaveland 1975) between 1725 and $1868(\mathrm{n}=144)$ (Table 4, Figure 3$)$. This result suggests that our 217-year floating shortleaf pine

Table 3. Descriptive statistics and results from the segment testing conducted by COFECHA for the 16 measured series.

\begin{tabular}{|c|c|c|c|c|c|c|c|}
\hline Series & Begin Year & End Year & Length & $\begin{array}{l}\text { No. of } \\
\text { Segments } \\
\text { Tested }\end{array}$ & $\begin{array}{c}\text { No. } \\
\text { Flagged } \\
\text { Segments }\end{array}$ & $\begin{array}{c}\text { Correlation } \\
\text { with } \\
\text { Master }\end{array}$ & $\begin{array}{c}\text { Mean } \\
\text { Sensitivity }\end{array}$ \\
\hline ATL002 & 1652 & 1792 & 141 & 6 & 0 & 0.68 & 0.23 \\
\hline ATL010 & 1684 & 1774 & 91 & 5 & 0 & 0.64 & 0.21 \\
\hline ATL008 & 1688 & 1804 & 117 & 6 & 0 & 0.64 & 0.26 \\
\hline ATL014 & 1707 & 1809 & 103 & 5 & 1 & 0.48 & 0.32 \\
\hline ATL012 & 1710 & 1797 & 88 & 5 & 0 & 0.62 & 0.37 \\
\hline ATL005 & 1719 & 1790 & 72 & 3 & 0 & 0.45 & 0.29 \\
\hline ATL015 & 1725 & 1780 & 56 & 3 & 0 & 0.69 & 0.18 \\
\hline ATL013 & 1726 & 1844 & 119 & 6 & 1 & 0.51 & 0.21 \\
\hline ATL018 & 1730 & 1868 & 139 & 7 & 0 & 0.46 & 0.31 \\
\hline ATL011 & 1739 & 1800 & 62 & 3 & 0 & 0.49 & 0.18 \\
\hline ATL009 & 1759 & 1841 & 83 & 4 & 0 & 0.43 & 0.21 \\
\hline \multicolumn{4}{|c|}{ Total or Mean: } & 81 & 2 & 0.57 & 0.24 \\
\hline
\end{tabular}


Table 4. Correlations of 50-year ring segments of our Forsyth County chronology with SC003 from Clemson Forest, South Carolina. NS $=$ not significant $(\mathrm{p}>0.05)$.

\begin{tabular}{ccc}
\hline $\begin{array}{c}50 \text {-year } \\
\text { Ring Segment }\end{array}$ & $\begin{array}{c}\text { Correlation } \\
\text { Coefficient }\end{array}$ & $\begin{array}{c}\text { Probability } \\
(\mathrm{p}<)\end{array}$ \\
\hline $1675-1724$ & 0.13 & NS \\
$1700-1749$ & 0.30 & 0.03 \\
$1725-1774$ & 0.48 & 0.001 \\
$1750-1799$ & 0.42 & 0.003 \\
$1775-1824$ & 0.40 & 0.002 \\
$1800-1849$ & 0.44 & 0.002 \\
$1825-1874$ & 0.35 & 0.01 \\
\hline
\end{tabular}

chronology from the house in Forsyth County extends from 1652 to 1868 . The relationship between the two series is less strong for the period 1684$1724(\mathrm{r}=0.13, \mathrm{p}>0.05)$ (Table 4), although some congruency exists in the longer-term decadal trends during this period (Figure 3).

\section{DISCUSSION}

The lack of confident dating for two of our samples could occur because (1) the outer rings are considerably older than outer rings in the other series, (2) their ring segments were affected by a local disturbance, which would weaken the relationship with ring segments from other trees, or (3) a number of missing rings precluded successful dating by either graphical or statistical techniques. The last observation is possible because some southern pine species respond to climate conditions early in the growing season (Grissino-Mayer et al. 1989; Grissino-Mayer and Butler 1993; Grissino-Mayer and Tepper 2002). Should growth be diminished early in the growing season because of poor climate conditions, the production of earlywood cells may be minimal or nonexistent, thus producing a latewood-on-latewood phenomenon (what we term "stacked latewood") which is difficult to distinguish visually. We have observed this phenomenon not only in shortleaf pine samples, but also in longleaf pines (Pinus palustris Mill.) from southern Georgia.

The lack of correspondence between our shortleaf pine chronology and the Clemson Forest reference chronology for the period 1684-1724 likely results from missing rings in our series that extend back this far. We could find no physical evidence on the eight wood sections that cover this period that suggests which rings were missing (possibly because of "stacked latewood"). The Clemson

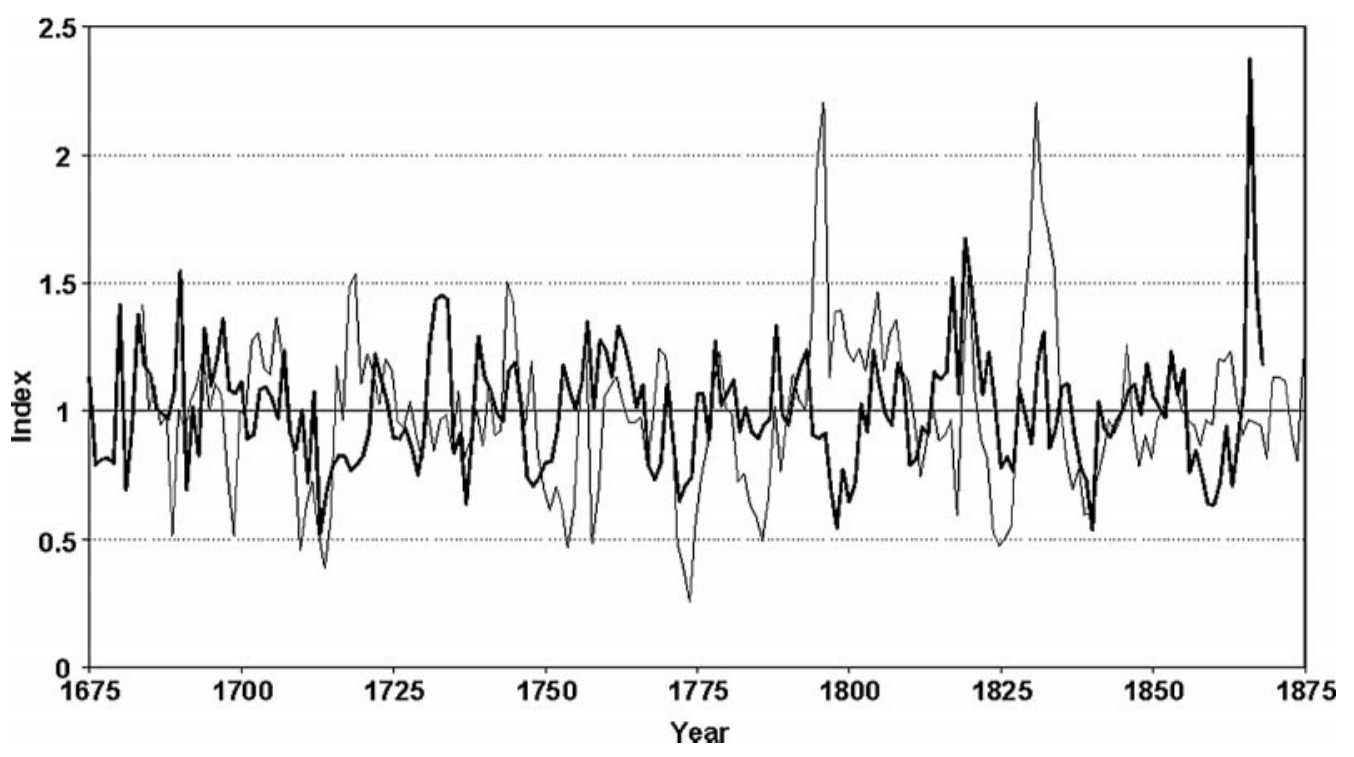

Figure 3. Comparison of the SC003 reference chronology (light line) with the Forsyth County shortleaf pine chronology developed in this study (darker line). 
Forest reference chronology showed low index values between 1710-1714, concurrent with a period of reduced growth in our shortleaf pine chronology (1710-1719, Figure 3). Furthermore, COFECHA showed a statistically significant correlation coefficient $(\mathrm{r}=0.39, \mathrm{p}<0.006, \mathrm{n}=50)$ between the two series for the earlier segment (1684-1733) after the Forsyth County chronology was adjusted by -2 years, i.e. two rings need to be inserted in the Forsyth County chronology. Several diagnostics provided by COFECHA (Grissino-Mayer 2001) indicate that these missing rings exist in the period 1710-1719. We currently have insufficient evidence as to which rings should be inserted as missing, but future collections that focus on sampling living old-growth shortleaf pines from this region or extracting samples from other Antebellum Period houses may resolve this issue.

We could not determine the exact year in which the trees were cut because the bark and outermost sapwood and some heartwood rings had been removed on all our samples as the beams were squared. Therefore, the outer rings could be far from the actual cutting date. The outer dates on 13 of the 16 samples, however, support that the house was built in the mid-1800s, but the lack of a clear cluster of outer dates precludes our assigning an 1851 construction date as suggested by its current owner. We observed that three timbers (ATL001, ATL017, and ATL018; Table 2) were installed in the house during the 1860 s, perhaps after it was built. These results indicate that one or more beams were added to the house in a later renovation (a sample-to-sample correlation analysis revealed that sections ATL001 and ATL017 were cut from the same tree). Nonetheless, the majority of outer dates strongly suggest a construction date for this house during the Antebellum Period.

This study represents the first dendrochronological dating of a historic structure in the state of Georgia and developed the first tree-ring chronology for northern Georgia that extends to the 17th Century. The statistically significant crossdating between the Clemson Forest shortleaf pine chronology and the Forsyth County shortleaf pine chronology suggests a strong macroclimatic signal across a broad region of the Piedmont physiographic province in the southeastern U.S. The cli- mate history for northern Georgia between 17201868 can now also be examined further using the information provided by this new chronology, although a larger sample size would be required for a more robust interpretation of past climate. Eventual resolution of the dating discrepancy will push this climate information back to 1652. Furthermore, it now may be possible to obtain dendrochronological dates for wooden structures from the region by using this new reference chronology, especially important given that northern Georgia has a long history of settlement by Native Americans and later by Euro-Americans. The historical interpretation of even well-documented buildings can also be significantly improved by using these new tree-ring data. Tree-ring dates may also be used as an independent check on the accuracy of documents referring to historic buildings.

\section{ACKNOWLEDGMENTS}

We thank Dr. Bryan Redd, Jr., for his sustained interest in the utility of dendrochronological dating. Without his assistance in supplying wood samples, helpful commentary, and necessary documentation, this project would not have been possible. We also thank Elizabeth Atchley and Daniel Lewis for helping prepare the samples, and Saskia van de Gevel-Edidin and Evan Larson for critically reading and commenting on earlier drafts of this paper. We also thank the many thoughtful contributors of tree-ring data to the International TreeRing Data Bank. Their contributions to a publiclyaccessible archive ensure that data are preserved for future generations of scientists.

\section{REFERENCES CITED}

Bannister, B.

1969 Dendrochronology. In Science in Archaeology: A Survey of Progress and Research, edited by D. Brothwell and E. Higgs, pp. 191-205. Praeger Publishers, New York.

Bell, R. E.

1952 Dendrochronology in the Mississippi Valley. In Archeology in the Eastern United States, edited by J. B. Griffin, pp. 345-351. University of Chicago Press, Chicago. 
Bortolot, Z. J., C. A. Copenheaver, R. L. Longe, and J. A. N. van Aardt

2001 Development of a white oak chronology using live trees and a post-Civil War cabin in south-central Virginia. Tree-Ring Research 57:197-203.

Carley, R.

1994 The Visual Dictionary of American Domestic Architecture. Henry Holt and Co., New York.

Cleaveland, M. K.

1975 Dendroclimatic Relationships of Shortleaf Pine (Pinus echinata Mill.) in the South Carolina Piedmont. M.S. thesis, Clemson University, South Carolina. Master's Abstracts 18(1):7. University Microfilms International, Ann Arbor.

Cook, E. R.

1985 A Time Series Analysis Approach to Tree-Ring Standardization. Ph.D. dissertation, University of Arizona, Tucson.

D'Arrigo, R. D., and G. C. Jacoby

1991 A 1000-year record of winter precipitation from northwestern New Mexico, USA: A reconstruction from tree-rings and its relation to El Niño and the Southern Oscillation. Holocene 1:95-101.

Dean, J. S.

1986 Dendrochronology. In Dating and Age Determination of Biological Materials, edited by M. R. Zimmerman and J. L. Angel, pp. 126-165. Croom Helm, London.

1996 Dendrochronology and the study of human behavior. In Tree Rings, Environment and Humanity, edited by J. S. Dean, D. M. Meko, and T. W. Swetnam, pp. 461-469. Radiocarbon, Tucson, Arizona.

Dean, J. S., and G. S. Funkhouser

1995 Dendroclimatic reconstructions for the southern Colorado Plateau. In Climate Change in the Four Corners and Adjacent Regions: Implications for Environmental Restoration and Land-Use Planning, edited by W. J. Waugh, pp. 85-104. Mesa State College, Grand Junction, Colorado.

DeWitt, E., and M. Ames

1978 Tree-ring chronologies of eastern North America. Laboratory of Tree-Ring Research, University of Arizona, Tucson, Arizona. Chronology Series IV, Volume 1.

Druckenbrod, D. L., M. E. Mann, D. W. Stahle, M. K. Cleaveland, M. D. Therrell, and H. H. Shugart

2003 Late-eighteenth-century precipitation reconstructions from James Madison's Montpelier plantation. Bulletin of the American Meteorological Society 84:5771.

Euler, R. C., G. J. Gumerman, T. N. V. Karlstrom, J. S. Dean, and R. H. Hevly

1979 The Colorado Plateaus: Cultural dynamics and palaeoenvironment. Science 205:1089-1101.

Fritts, H. C.

2001 Tree Rings and Climate. Blackburn Press, Caldwell, New Jersey.
Gleason, D. K.

1987 Antebellum Homes of Georgia. Louisiana State University Press, Baton Rouge.

Grissino-Mayer, H. D.

2001 Evaluating crossdating accuracy: A manual and tutorial for the computer program COFECHA. TreeRing Research 57:205-221.

Grissino-Mayer, H. D., and D. R. Butler

1993 Effects of climate on growth of shortleaf pine (Pinus echinata Mill.) in northern Georgia: A dendroclimatic study. Southeastern Geographer 33:65-81.

Grissino-Mayer, H. D., M. S. Rosenberger, and D. R. Butler

1989 Climatic response in tree rings of loblolly pine from north Georgia. Physical Geography 10:32-43.

Grissino-Mayer, H. D., and J. H. Tepper

2002 Decadal-scale trends in a dendroclimatic reconstruction of annual precipitation for southern Georgia. Program with Abstracts, Annual Meeting of the Association of American Geographers, 19-23 March 2002, Los Angeles, California.

Hally, D. J.

1988 Archaeology and settlement plan of the King Site. In The King Site: Continuity and Contact in SixteenthCentury Georgia, edited by R. L. Blakely, pp. 3-16. The University of Georgia Press, Athens.

Hawley, F. M

1938 Tree-ring dating for southeastern mounds. In $\mathrm{An} A r$ chaeological Survey of the Norris Basin in Eastern Tennessee, edited by W. S. Webb, pp. 359-362. Bureau of American Ethnology Bulletin 118. Washington, D.C.

Holmes, R. L.

1983 Computer-assisted quality control in tree-ring dating and measurement. Tree-Ring Bulletin 43:69-78.

1992a The Dendrochronology Program Library. In International Tree-Ring Data Bank Program Library User's Manual, edited by H. D. Grissino-Mayer, R. L. Holmes, and H. C. Fritts, pp. 40-74. Laboratory of Tree-Ring Research, University of Arizona, Tucson.

1992b Program CRONOL. In International Tree-Ring Data Bank Program Library User's Manual, edited by H. D. Grissino-Mayer, R. L. Holmes, and H. C. Fritts, pp. 56-57. Laboratory of Tree-Ring Research, University of Arizona, Tucson.

International Tree-Ring Data Bank (ITRDB)

2003 Data available at http://www.ngdc.noaa.gov/paleo/ treering.html.

Langley, S. B. M.

2000 Tongues in trees: archaeology, dendrochronology, and the Mulberry Landing wharf. Maryland Historical Magazine 95:339-348.

Mann, D. F.

2002 The Dendroarchaeology of the Swaggerty Blockhouse, Cocke County, Tennessee. M.S. thesis, University of Tennessee, Knoxville. 
Nash, S.

1999 Time, Trees, and Prehistory: Tree-Ring Dating and the Development of North American Archaeology, 1914-1950. University of Utah Press, Salt Lake City.

Orvis, K. H., and H. D. Grissino-Mayer

2002 Standardizing the reporting of abrasive papers used to surface tree-ring samples. Tree-Ring Research 58: $47-50$.

Scheffer, T. C.

1972 A climate index for estimating potential decay in wood structures above ground. Forest Products Journal 21:25-31.

Shadburn, D. L.

1990 Cherokee Planters in Georgia 1832-1838. W. H. Wolfe Associates, Historical Publications Division, Roswell, Georgia.
Stahle, D. W.

1979 Tree-ring dating of historic buildings in Arkansas. Tree-Ring Bulletin 39:1-28.

Stahle, D. W., and D. Wolfman

1985 The potential for archaeological tree-ring dating in eastern North America. In Advances in Archaeological Method and Theory, Volume 8, edited by M. B. Schiffer, pp. 279-302. Academic Press, New York.

Wilms, D. C.

1973 Cherokee Indian Land Use in Georgia, 1800-1838. $\mathrm{Ph}$.D. Dissertation, University of Georgia.

1991 Cherokee land use in Georgia before removal. In Cherokee Removal: Before and After, edited by W. L. Anderson, pp. 1-28. The University of Georgia Press, Athens.

Received 6 January 2004; accepted 30 August 2004. 